\title{
Understanding Student Perceptions of Diversity in Education
}

\author{
Savanna M. Love \\ Randolph-Macon College \\ Diana M. Yesbeck
Randolph-Macon College
}

This qualitative study evaluates teacher candidates' understanding of diversity related to teaching and provides validity data for our teacher preparation program's Diversity Reflection assessment. We analyze reflections from teacher candidates during three stages of their program to identify areas for improvement in our instruction and assessment of this topic. Data demonstrate emergent themes related to what students understand about diversity as well as areas of growth for students and faculty. Results indicate a need to focus instruction on an in-depth understanding of the different types of diversity, reflection on candidates' own positionality and how they may differ from their students, and the importance of collaboration with stakeholders in supporting diverse learners. Implications for assessment, instrument validity and program evaluation are also discussed.

Keywords: diversity, teacher preparation, instruction, assessment, improvement

\section{INTRODUCTION}

Producing quality teachers who can positively impact student achievement is the goal of any teacher preparation program. More than ever before, we are aware of the critical role teachers and classroom instruction play in student to teacher relations, student to student relations, understanding classroom cultures and diversity, and student performance. As classrooms around the world are becoming more diverse, preparing teachers for diversity and inclusion is becoming a global concern. There is an increasing need for teachers who can work with the experiences, values, approaches and abilities of diverse student populations (Lewis Chui et al., 2017). Teacher preparation programs play a critical role in preparing preservice teachers to respond to the diverse educational needs of all students in the classroom (CardonaMolto, et al., 2018).

Our Educator Preparation Program (EPP) relies on a quality assurance system to monitor and evaluate various aspects of the program to ensure that standards of quality are being met. One area of focus for our program is preparing teacher candidates to understand learning differences, learning environments, and diverse classroom cultures. Specifically, the EPP outlines course goals and objectives, using the Interstate New Teacher Assessment and Support Consortium (InTASC) standards, to prepare teacher candidates in understanding individual differences and diverse cultures and communities to ensure inclusive learning environments that enable each learner to meet high standards, encourage positive social interaction and active engagement in learning, and supports self-motivation. In order to evaluate the effectiveness of our 
program in meeting these standards, our EPP employs time-series assessments to measure candidates' growth over time. One of these time-series assessments, the Diversity Reflection, relates specifically to candidates' understanding of diversity in education.

The purpose of this study is to investigate teacher candidates' understanding of diversity related to teaching and learning using the Diversity Reflection. It was first designed to meet national accreditation standards and has since been used to support continuous improvement efforts related to diversity and multicultural education. This study will assist EPP faculty in determining validity of the Diversity Reflection assessment and offer insight into a potential model for evaluating a program's efforts to prepare teacher candidates in understanding and supporting diverse populations of students.

\section{PERSPECTIVES FROM THE LITERATURE}

Teacher preparation programs have addressed the need to prepare culturally competent teachers for some time, and for many programs, it is mandated by accreditation boards. Recognizing the critical role that culturally competent teachers play in the academic success of students from diverse backgrounds, The Council for the Accreditation of Education Preparation (CAEP) emphasized the importance of preparing teachers to be culturally competent, stating that "Diversity must be a pervasive characteristic of any quality preparation program (CAEP Board of Directors, 2015, p. 21). CAEP defines diversity as "(1) individual differences (e.g., personality, interests, learning modalities, and life experiences, and (2) group differences (e.g. race, ethnicity, ability, gender identity, gender expression, sexual orientation, nationality, language, religion, political affiliation, and socio-economic background)" (InTASC Model Core Teaching Standards, p. 21). Teacher preparation programs are expected to embed concepts related to diversity into all aspects of course content. CAEP specifically suggests that coursework should prepare candidates to incorporate multiple perspectives, deepen awareness of diverse learners for planning instruction, foster verbal and nonverbal communication skills that demonstrate respect for diverse students and their families, and support preservice teachers' understanding of their own culture and biases they may hold (Chui et al, 2017). To meet CAEP standards, many teacher preparation programs have implemented new courses to address diversity and multicultural education, while others have embedded goals and objectives related to multicultural education throughout their programs, and still others have attempted to do both.

Researchers have investigated the effect of a required diversity or multicultural course on preservice teachers' cultural competence and attitudes towards diverse populations and have found mixed results (i.e. Brown, 2004; Lana, 2014; Middleton, 2002; Puchner et al., 2012; Valentin, 2006). For example, Brown (2004) found that one stand-alone course has the potential to increase factors of cultural diversity awareness while not influencing others. Similarly, Middleton (2002) examined changes in attitudes, beliefs, and commitment towards diversity of preservice teachers after completing a required course and found that while there was a significant overall difference in self-reported personal beliefs at the conclusion of the course, these changes were not always toward increased diversity beliefs and commitment. According to Lana (2014), too many courses have been found to celebrate diversity rather than explore critical approaches to handling it. Puchner and colleagues (2012) point out that college courses addressing diversity training and multicultural education are inconsistent in terms of content, teaching strategies and quality, making it difficult to draw conclusions about the effectiveness of these types of courses overall. Valentin (2006) aligns in her statement that "instructional methodology may make a difference in the effect of diversity courses" (p. 198), and further argues that while stand-alone courses may be effective in some situations, teacher education programs must also infuse diversity objectives throughout each course offered and ensure that preservice teachers have opportunities to interact with students from diverse backgrounds.

These inconsistencies in the literature highlight a need to evaluate teacher preparation programs on the ways in which courses and coursework address diversity and inclusion and identify potential areas for improvement. As Valentin (2006) states, "to productively and reasonably achieve the design and implementation associated with training teachers to foster diversity, it is critical that teacher education programs are sensitively examined (p.201)." Thus, the purpose of this research is to carefully examine teacher candidates' progress in understanding diversity and the skills and knowledge necessary to teach 
diverse student populations. Doing so will provide insight into effective ways in which programs can offer and promote consistency in the approach and delivery of diversity and diversity issues.

\section{METHODOLOGY}

This qualitative study measures teacher candidates' understanding of diversity in education as candidates progress through a teacher preparation program. The following sections discuss the context of the teacher preparation program for this study, the participants, instrumentation and data analysis.

\section{Teacher Preparation Program Context}

The EPP offers a state approved and nationally accredited undergraduate program which certifies that the professional education program has provided evidence which adheres to CAEP's quality principles. The structured programs enable students to meet the requirements prescribed by the State Board of Education for the Collegiate Professional License in fourteen endorsements. In our EPP prior to spring 2021, the topics of understanding student diversity and classroom cultures in K-12 schools were embedded in preparation courses across all endorsement programs. Using activities, discussions, and journal articles, teacher candidates gain a deeper understanding of learners, their needs and differences, and the diversity which makes up K-12 classrooms. As teacher candidates prepare to become culturally responsive teachers, the EPP uses the Diversity Reflection to gain an understanding of the candidates' perspectives and growth. In spring 2021, the EPP began offering a Diversity in Education course which is now required for all endorsement programs. With the addition of this course, we anticipate students' perceptions of student diversity to meet program expectations, demonstrating a greater understanding of student diversity in K-12 classrooms. More of this is included in the Discussion section of the paper.

Teacher candidates write their Diversity Reflection at three times during their tenure through the teacher preparation program. The current study analyzed diversity reflections from students at each of the three points during the Spring 2020 semester - at the beginning of the program, at midpoint, and at the end during their clinical experience as a student teacher. All students completed the assignment for their respective classes and were then invited to opt-in to the study by agreeing for their diversity reflection to be included in this research. On average, the EPP enrolls 50-60 candidates each academic year in education courses.

\section{Participants}

Participants for this study included 38 teacher candidates. From the 38 participants, $47 \%$ were enrolled in the elementary education program, $39 \%$ enrolled in the secondary education programs, $11 \%$ enrolled in the special education program, and 3\% were enrolled in the music education program. Seniors were most represented from the group, making up $47 \%$ of the participants, juniors made up 34\%, and sophomores made up 19\%. A larger group of female participants were represented, making up 87\%, while only $13 \%$ of the group were males. Consistent with the broader college community, participants racial identity includes $82 \%$ White, $10 \%$ Black, and $8 \%$ Hispanic.

\section{Instrument}

Using the InTASC standards as the guiding principle, EPP faculty created the Diversity Reflection focusing on four questions listed below. Teacher candidates are encouraged to use experiences from coursework, fieldwork, and student teaching to support their answers. The assessment is given at three times during a candidate's progress through the preparation program - at the beginning of the program in the first course; in the middle of the program, and at the end of the program during the clinical experience as a student teacher. Candidates provide a reflection in a double-spaced three-paged response.

1. What sorts of diversity might you encounter among your students as a teacher?

2. What is a teacher's responsibility with regards to teaching diverse learners?

3. What knowledge, skills and dispositions must a teacher have to teach diverse students well?

4. What do you need to know about self and others to teach diverse students well? 
EPP faculty score the reflections using the attached rubric (see Appendix A). During the pilot year of administration, EPP faculty established inter-rater reliability by reviewing the same samples of candidate work; assigned scores, and then discussed the understanding of each assessment item and related score. If discrepancies existed, then evaluators had conversations about the meaning of the assessment item. At the end of each semester, EPP faculty hold data analysis meetings to discuss the candidates' understanding of diversity and determine areas for improvement. EPP faculty also expect to see candidate growth over time.

\section{Data Analysis}

The current study employed a hybrid coding approach (Saldaña, 2015), and diversity reflections were coded using Atlas.ti 7.5.18. Codes were initially created to correspond to the InTASC standards presented in Table 1. Additional codes were created as necessary to reflect emerging themes in the data. One member of the team coded the reflections, and the second member acted as a reader. The team met to discuss discrepancies for inter-rater agreement and identified emerging themes. This process continued until both researchers reached a consensus.

\section{RESULTS}

Seven themes emerged from the findings: (1) a lack of deep understanding of types of diversity, particularly in early years (2) a commitment to knowing students well; (3) teachers have the responsibility to provide equal education opportunities and equity; (4) differentiation and communication were identified as a key skills needed to teach diverse learners; (5) patience and acceptance were identified as important dispositional characteristics to teach diverse learners; (6) teachers should establish a welcoming classroom that embraces and celebrates diversity; and (7) teachers must become educated about diversity.

Most candidates identified a number of different types of diversity. However, many candidates did not elaborate or elaborated very little on these examples of diversity and therefore did not demonstrate an indepth understanding of what these differences might look like in a classroom and how they might impact learning. As one sophomore described, "Whether it be gender, racial, socio-economic, ability/disability, ethnic, or religious, there will always be at least one way that students differ from one another. For example, the class I am doing my fieldwork with is diverse by way of gender, race, ethnicity, and religion. In terms of race, most of the students are Indian, but there are also some white, African-American, and middleeastern students." Similarly, a senior wrote, "We can have students of different race, class, gender, or sexual orientation. We can have students who come from different backgrounds, life experiences, and world views. We can have students with different likes and interests. We can also have students who learn differently from one another; some might be better visual learners, while others may learn better kinesthetically. The possibility of teaching two students who are exactly alike are slim." It should be noted that in general, candidate descriptions of diversity and use of examples improved as they continued through the program.

Candidates overwhelmingly discussed a commitment to knowing their students well. For example, one sophomore wrote, "as a teacher, it is very important to get a good understanding of the students at the beginning of the year so you can figure out how to best meet everyone's needs," while a senior wrote, "I think the most important thing to know when teaching diverse learners is to know the students themselves. Having good relationships with your students is so important to a successful learning environment for any diverse learner." In general, students consistently discussed the importance of building relationships and learning the backgrounds of their students in order to understand how to meet their needs in the classroom.

Most candidates also discussed the importance of providing equal education opportunities to all students. For example, a sophomore candidate wrote, "teachers must apply their awareness of diversity to ensure that they are doing everything in their power to better the education of their students and provide all students with an opportunity to grow and develop to the best of their ability." Some also described the difference in equality and equity, stressing the importance of providing students with the supports they need for the classroom to be an equitable place of learning. As one junior described, "It is important to know that equity and equality are not the same. Equality is giving every student the same things, whereas equity means giving each student what they need to be successful." 
Candidates consistently discussed differentiation as an important skill that teachers need to teach diverse learners. For example, a senior described, "I would implement differentiation in all my lessons. I would do this in order to try and reach all my learners and to make sure I am engaging my students. I would also ask the students what they prefer; such as if they are visual learners or if they prefer notes." While students often discussed using various instructional strategies, very few specifically mentioned using differentiated assessment techniques. Candidates also included communication as a critical skill in teaching diverse learners. While some explained that communication was important for establishing relationships with students, others discussed how communication skills allowed teachers to effectively teach content using a variety of strategies. As one sophomore wrote, "the last skill that I think would be very crucial in the success of teaching diverse learners is an ability to be an effective communicator. You may understand the content perfectly as the teacher, but if you are not able to effectively communicate the content to your students and adapt to help them understand it, then unfortunately the students will most likely not grasp the information very well."

Being patient and accepting were two of the most common dispositional characteristics candidates discussed as requirements to teach diverse learners. As one sophomore wrote, "Teachers must be accepting of all students and always set positive expectations," then a senior explained, "patience is important when interacting with students. In order to recognize that she has diverse students, a teacher must know her students, and she can only know them over time. Students typically do not open up about themselves immediately. They need a relationship built on trust before they make themselves vulnerable, and it takes time to build that trust. However, patience is also needed to handle those differences that are made apparent right away." While not always discussed together, these two dispositional characteristics encompass the recurring ideas across all three groups of students.

A majority of the candidates discussed the importance of creating a welcoming classroom that embraces and celebrates diversity. Candidates demonstrated a clear understanding of the important role classroom environment can play in student success. As one junior described, "We must recognize that embracing diversity takes effort but it is extremely important. If teachers can create a classroom that is welcoming as diversity and sees it as a strength, rather than a weakness, each student will reap greater academic benefits and our relationship with our students and between students will be so much stronger and more learning will occur!" Some candidates referenced identifying and removing negative behaviors such as bullying, and others discussed specific ways in which they might celebrate student differences in their classroom. For example, a sophomore shared, "diversity is not something that should be ignored or fixed; rather it should be celebrated. It is important, especially for young children, to celebrate our differences and appreciate the contributions of all different people."

Lastly, many candidates discussed the importance of teachers becoming educated about diversity in order to understand how to best support their students. Some acknowledged the reality that being prepared to teach all types of diverse learners would require ongoing professional development, and others acknowledged the necessity of learning about their students' cultures in order to make connections with them. For example, one sophomore discussed how, "both teachers and students should be educated on diversity and learn different ways to approach it. Diversity is key in the 21st century as it proceeds to grow every year. Without diversity, the United States would not be the country it is today," while a senior wrote that teachers, "must have, or seek out, the knowledge of different cultures, languages, home styles, disabilities, learning preferences, and other factors that make our students diverse. Teachers should first educate themselves before educating their students."

Other important findings from this study included the items on the diversity reflection rubric that did not emerge as themes. Students did not discuss the importance of collaborating with stakeholders to meet the needs of diverse learners, nor did they often discuss acknowledging the ways in which their experience may differ from students. 


\section{DISCUSSION AND SIGNIFICANCE}

The findings presented here demonstrate both the strengths and weaknesses of our students' knowledge related to diversity in education. These findings are important at the program level as they inform instruction of our candidates moving forward. Specifically, courses should include instruction on an in-depth understanding of the different types of diversity that candidates will encounter in the classroom, reflection on candidates' own positionality and how they may differ from their students, and the importance of collaboration with stakeholders in supporting diverse learners.

This research also highlights some inconsistencies with what our instrument is asking students to do and the way in which we are scoring them. For instance, one rubric item requires candidates to discuss collaboration with families and school community members, though our questions do not prompt students to discuss this specifically. This item reads: "Candidate demonstrates understanding that a teacher has a responsibility to collaborate with students, families and school community members to meet the needs of diverse learners," and the question that is designed to get at this idea is "What is a teacher's responsibility with regards to teaching diverse learners?" However, it may not be clear from the question that students should be discussing collaboration with specific stakeholders. Students also identified some important ideas about teaching diverse learners (i.e., becoming educated about diversity) that are not reflected in our rubric. Thus, it may be worth reviewing the questions we are asking candidates as well as the rubric we use to score them in order to identify any areas of confusion or potential revision for better alignment of the instrument and rubric.

The current research may also provide a useful model for consideration in analyzing student perceptions of diversity in education. Previous literature has indicated mixed results regarding the effective strategies for addressing multicultural education and diversity training (i.e. Brown, 2004; Lana, 2014; Middleton, 2002; Puchner et al., 2012; Valentin, 2006). Thus, it is critical for teacher preparation programs to carefully evaluate the models used to assess student learning in this area. Our model of embedding diversity and multicultural objectives and goals throughout all of our courses and assessing students at three points during their program may be of use to other teacher preparation programs looking for ways to evaluate their own students and programs. Importantly, part of our program's continuous improvement model has been to add a Diversity in Education course as a required course for all students. We began offering this course in spring 2021, and we predict that beginning with graduating class of 2023, the transition in adding this required course will be complete.

This Diversity in Education course is designed to clarify and develop future teachers' understanding of diversity and teaching children from diverse backgrounds through an exploration of multicultural education. In this course, diversity refers to all ways in which people differ, including ethnicity, language, religious practices, sexual preferences, disability, socio-economic status, gender, and other differences. It therefore provides opportunities to learn more about cultural pluralism and diversity, confront racism and other biases, view history and current events from a variety of perspectives, and think about teaching in a multicultural manner within any school context. (See Appendix B for additional information on the course objectives and standards.)

With the offering of this new required course, we align with teacher preparation programs across the nation to better equip our students with the importance of understanding diverse learners and to best meet the needs of all learners. This course, in conjunction with the diversity objectives we have embedded throughout our program, will support us in our efforts to ensure that our candidates are prepared to be culturally competent teachers. As an EPP, we are committed to engaging in continued professional development for all instructors to become better qualified and more confident to teach and assess in this area. For the continued work we do as an EPP, it will also be important to compare student progress over time and continue to evaluate the effectiveness of these strategies in supporting our students' understanding of multicultural education and diversity.

Ultimately, it is critical for teacher education programs to continuously evaluate their effectiveness in preparing culturally competent teachers. As programs around the country work to respond to accreditation and school requirements to ensure teacher candidates are prepared for diverse classrooms models for 
evaluation and continuous improvement are critical to our success. Future research should continue to consider the ways in which we might evaluate teacher candidates' learning with regard to diversity, how teacher education programs can reliably measure this learning, and the strategies that best foster student understanding of diversity.

\section{REFERENCES}

Brown, E.L. (2004). What precipitates change in cultural diversity awareness during a multicultural course: The message or the method? Journal of Teacher Education, 55(4), 325-340.

Cardona Moltó, M.C., Rao, S., Chiner, E., \& Soffer, R. (2018). Exploring Attitudes and Competence to Teach Diverse Students: A Cross-cultural Study of Teacher Perceptions in Spain and the United States. The International Journal of Diversity in Education, 17(4).

Council for the Accreditation of Educator Preparation (CAEP Board of Directors). (2015). CAEP accreditation standards. Washington, DC: Council for the Accreditation of Educators Preparation.

Ellerbrock, C.R., Cruz, B.C., Vásquez, A., \& Howes, E.V. (2016). Preparing culturally responsive teachers: Effective practices in teacher education. Action in Teacher Education, 38(3), 226-239.

Krippendorff, K. (2009). Testing the Reliability of Central Analysis Data: What is Involved and Why. In K.H. Krippendorff \& M.A. Bock (Eds.), The Content Analysis Reader (pp. 350-357). Thousand Oaks, CA: Sage Publication.

Lewis Chiu, C., Sayman, D., Carrero, K.M., Gibbon, T., Zolkoski, S.M., \& Lusk, M.E. (2017). Developing culturally competent preservice teachers. Multicultural Perspectives, 19(1), 47-52.

Middleton, V.A. (2002). Increasing preservice teachers' diversity beliefs and commitment. The Urban Review, 34(4), 343-361.

Milner, H.R., \& Laughter, J.C. (2015). But good intentions are not enough: Preparing teachers to center race and poverty. The Urban Review, 47(2), 341-363.

Puchner, L., Szabo, Z., \& Roseboro, D.L. (2012). The short-term effect of a race-related course on racial identity of White students. Teaching in Higher Education, 17(4), 399-410.

Saldaña, J. (2015). The coding manual for qualitative researchers. Los Angeles: Sage Publications.

Valentíin, S. (2006). Addressing diversity in teacher education programs. Education, 127(2).

Worrell, F.C., Brabeck, M.M., Dwyer, C.A., Geisinger, K.F., Marx, R.W., Noell, G.H., \& Pianta, R.C. (2014). Assessing and evaluating teacher education programs. Washington, DC: American Psychological Association. Retrieved from https://drupal.bear.berkeley.edu/sites/default/files/Worrell.BEAR\%20Center.pdf 


\section{APPENDIX A: DIVERSITY REFLECTION EVALUATION RUBRIC}

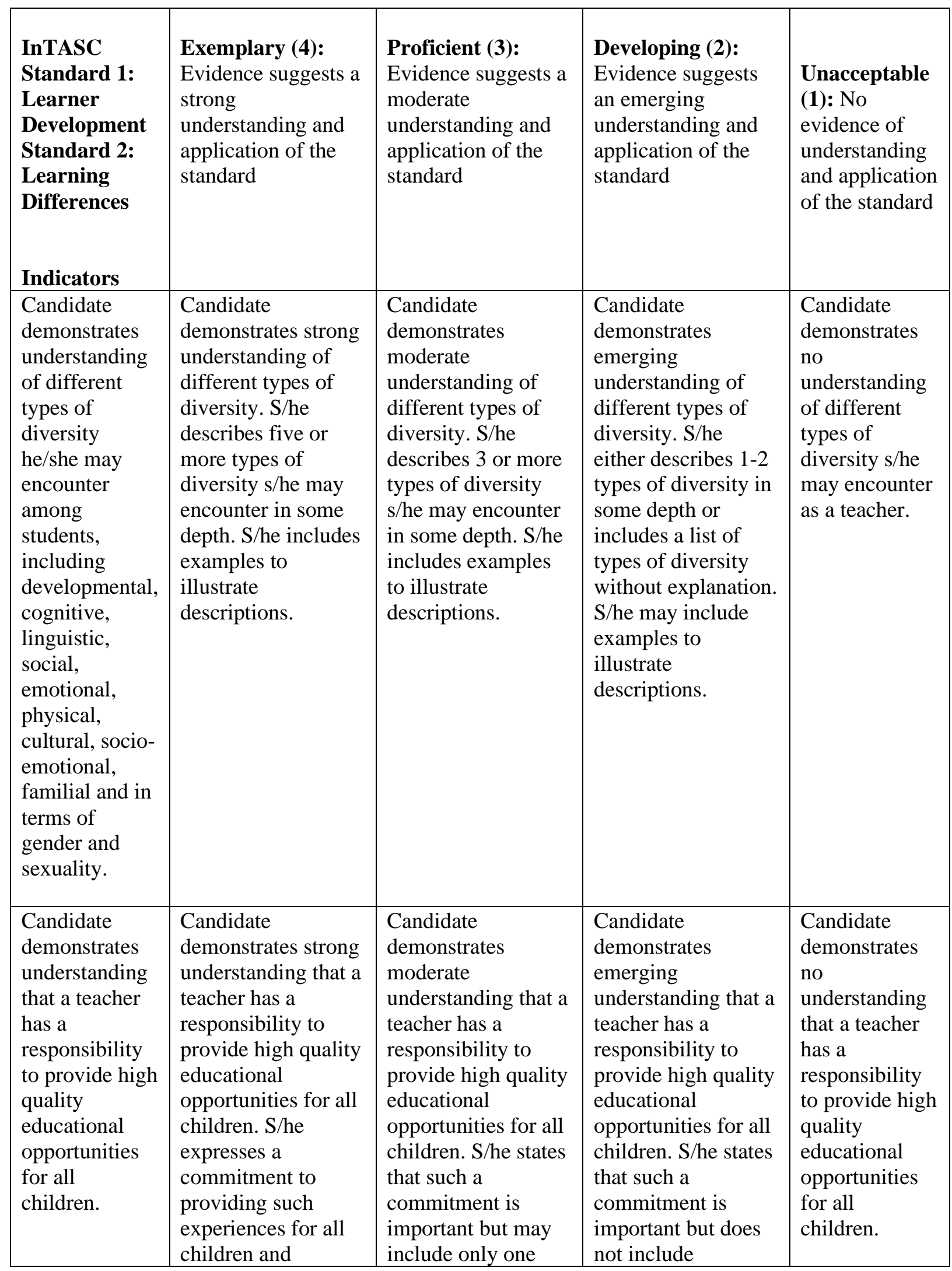




\begin{tabular}{|c|c|c|c|c|}
\hline & $\begin{array}{l}\text { includes at least two } \\
\text { examples to } \\
\text { illustrate how a } \\
\text { teacher might do so. }\end{array}$ & $\begin{array}{l}\text { example to illustrate } \\
\text { how a teacher might } \\
\text { live this } \\
\text { commitment }\end{array}$ & $\begin{array}{l}\text { examples to } \\
\text { illustrate how a } \\
\text { teacher might live } \\
\text { this commitment. }\end{array}$ & \\
\hline $\begin{array}{l}\text { InTASC } \\
\text { Standard 1: } \\
\text { Learner } \\
\text { Development } \\
\text { Standard 2: } \\
\text { Learning } \\
\text { Differences }\end{array}$ & $\begin{array}{l}\text { Exemplary (4): } \\
\text { Evidence suggests a } \\
\text { strong } \\
\text { understanding and } \\
\text { application of the } \\
\text { standard }\end{array}$ & $\begin{array}{l}\text { Proficient (3): } \\
\text { Evidence suggests a } \\
\text { moderate } \\
\text { understanding and } \\
\text { application of the } \\
\text { standard }\end{array}$ & $\begin{array}{l}\text { Developing (2): } \\
\text { Evidence suggests } \\
\text { an emerging } \\
\text { understanding and } \\
\text { application of the } \\
\text { standard }\end{array}$ & $\begin{array}{l}\text { Unacceptable } \\
\text { (1): No } \\
\text { evidence of } \\
\text { understanding } \\
\text { and application } \\
\text { of the standard }\end{array}$ \\
\hline \multicolumn{5}{|l|}{ Indicators } \\
\hline $\begin{array}{l}\text { Candidate } \\
\text { demonstrates } \\
\text { understanding } \\
\text { that a teacher } \\
\text { has a } \\
\text { responsibility } \\
\text { to know } \\
\text { his/her } \\
\text { students well. }\end{array}$ & $\begin{array}{l}\text { Candidate } \\
\text { demonstrates a } \\
\text { strong } \\
\text { understanding that a } \\
\text { teacher has a } \\
\text { responsibility to } \\
\text { know his/her } \\
\text { students well. S/he } \\
\text { expresses a } \\
\text { commitment to } \\
\text { knowing students } \\
\text { well and offers two } \\
\text { or more examples to } \\
\text { illustrate how a } \\
\text { teacher might build } \\
\text { such knowledge. }\end{array}$ & $\begin{array}{l}\text { Candidate } \\
\text { demonstrates a } \\
\text { moderate } \\
\text { understanding that a } \\
\text { teacher has a } \\
\text { responsibility to } \\
\text { know his/her } \\
\text { students well. S/he } \\
\text { states that such } \\
\text { understanding is } \\
\text { important and offers } \\
\text { an example to } \\
\text { illustrate how a } \\
\text { teacher might build } \\
\text { such knowledge. }\end{array}$ & $\begin{array}{l}\text { Candidate } \\
\text { demonstrates a } \\
\text { emerging } \\
\text { understanding that a } \\
\text { teacher has a } \\
\text { responsibility to } \\
\text { know his/her } \\
\text { students well. S/he } \\
\text { states that such } \\
\text { understanding is } \\
\text { important but may } \\
\text { not include } \\
\text { examples to } \\
\text { illustrate how a } \\
\text { teacher would build } \\
\text { such knowledge. }\end{array}$ & $\begin{array}{l}\text { Candidate } \\
\text { demonstrates } \\
\text { no } \\
\text { understanding } \\
\text { that a teacher } \\
\text { has a } \\
\text { responsibility } \\
\text { to know } \\
\text { his/her } \\
\text { students well. }\end{array}$ \\
\hline $\begin{array}{l}\text { Candidate } \\
\text { demonstrates } \\
\text { understanding } \\
\text { that a teacher } \\
\text { has a } \\
\text { responsibility } \\
\text { to collaborate } \\
\text { with students, } \\
\text { families and } \\
\text { school } \\
\text { community } \\
\text { members to } \\
\text { meet the needs } \\
\text { of diverse } \\
\text { learners. }\end{array}$ & $\begin{array}{l}\text { Candidate } \\
\text { demonstrates a } \\
\text { strong } \\
\text { understanding that a } \\
\text { teacher has a } \\
\text { responsibility to } \\
\text { collaborate with } \\
\text { students, families } \\
\text { and school } \\
\text { community } \\
\text { members to meet } \\
\text { the needs of diverse } \\
\text { learners. S/he } \\
\text { expresses a } \\
\text { commitment to } \\
\text { collaborate and } \\
\text { offers examples to } \\
\text { illustrate how a } \\
\text { teacher might }\end{array}$ & $\begin{array}{l}\text { Candidate } \\
\text { demonstrates a } \\
\text { moderate } \\
\text { understanding that a } \\
\text { teacher has a } \\
\text { responsibility to } \\
\text { collaborate with } \\
\text { students, families } \\
\text { and school } \\
\text { community } \\
\text { members to meet } \\
\text { the needs of diverse } \\
\text { learners. S/he states } \\
\text { that such } \\
\text { collaboration is } \\
\text { important and offers } \\
\text { an example to } \\
\text { illustrate how a } \\
\text { teacher might }\end{array}$ & $\begin{array}{l}\text { Candidate } \\
\text { demonstrates an } \\
\text { emergent } \\
\text { understanding that a } \\
\text { teacher has a } \\
\text { responsibility to } \\
\text { collaborate with } \\
\text { students, families } \\
\text { and school } \\
\text { community } \\
\text { members to meet } \\
\text { the needs of diverse } \\
\text { learners. S/he states } \\
\text { that such } \\
\text { collaboration is } \\
\text { important but may } \\
\text { not offer an } \\
\text { example to illustrate }\end{array}$ & $\begin{array}{l}\text { Candidate } \\
\text { demonstrates } \\
\text { no } \\
\text { understanding } \\
\text { that a teacher } \\
\text { has a } \\
\text { responsibility } \\
\text { to collaborate } \\
\text { with students, } \\
\text { families and } \\
\text { school } \\
\text { community } \\
\text { members to } \\
\text { meet the needs } \\
\text { of diverse } \\
\text { learners. }\end{array}$ \\
\hline
\end{tabular}




\begin{tabular}{|c|c|c|c|c|}
\hline & $\begin{array}{l}\text { collaborate with two } \\
\text { or more of these } \\
\text { parties. }\end{array}$ & $\begin{array}{l}\text { collaborate with one } \\
\text { of these parties. }\end{array}$ & $\begin{array}{l}\text { how a teacher might } \\
\text { collaborate. }\end{array}$ & \\
\hline $\begin{array}{l}\text { InTASC } \\
\text { Standard 1: } \\
\text { Learner } \\
\text { Development } \\
\text { Standard 2: } \\
\text { Learning } \\
\text { Differences }\end{array}$ & $\begin{array}{l}\text { Exemplary (4): } \\
\text { Evidence suggests a } \\
\text { strong } \\
\text { understanding and } \\
\text { application of the } \\
\text { standard }\end{array}$ & $\begin{array}{l}\text { Proficient (3): } \\
\text { Evidence suggests a } \\
\text { moderate } \\
\text { understanding and } \\
\text { application of the } \\
\text { standard }\end{array}$ & $\begin{array}{l}\text { Developing (2): } \\
\text { Evidence suggests } \\
\text { an emerging } \\
\text { understanding and } \\
\text { application of the } \\
\text { standard }\end{array}$ & $\begin{array}{l}\text { Unacceptable } \\
\text { (1): No } \\
\text { evidence of } \\
\text { understanding } \\
\text { and application } \\
\text { of the standard }\end{array}$ \\
\hline \multicolumn{5}{|l|}{ Indicators } \\
\hline $\begin{array}{l}\text { Candidate } \\
\text { demonstrates } \\
\text { understanding } \\
\text { that a teacher } \\
\text { has an ethical } \\
\text { responsibility } \\
\text { to } \\
\text { acknowledge } \\
\text { the ways in } \\
\text { which his/her } \\
\text { experience } \\
\text { may differ } \\
\text { from students } \\
\text { and show } \\
\text { respect for } \\
\text { those } \\
\text { differences. }\end{array}$ & $\begin{array}{l}\text { Candidate } \\
\text { demonstrates a } \\
\text { strong } \\
\text { understanding that a } \\
\text { teacher has an } \\
\text { ethical } \\
\text { responsibility to } \\
\text { acknowledge the } \\
\text { ways in which } \\
\text { his/her experience } \\
\text { may differ from } \\
\text { students and show } \\
\text { respect for those } \\
\text { differences. S/he } \\
\text { reflects on at least } \\
\text { two ways that her } \\
\text { own identity may } \\
\text { differ from her past } \\
\text { or future students, } \\
\text { offering clear } \\
\text { examples. S/he } \\
\text { expresses respect } \\
\text { for others' } \\
\text { experience. S/he } \\
\text { expresses humility } \\
\text { in the face of what } \\
\text { s/he may not know } \\
\text { about others' } \\
\text { experience. }\end{array}$ & $\begin{array}{l}\text { Candidate } \\
\text { demonstrates a } \\
\text { moderate } \\
\text { understanding that a } \\
\text { teacher has an } \\
\text { ethical } \\
\text { responsibility to } \\
\text { acknowledge the } \\
\text { ways in which } \\
\text { his/her experience } \\
\text { may differ from } \\
\text { students and show } \\
\text { respect for those } \\
\text { differences. S/he } \\
\text { reflects on at least } \\
\text { one way that her } \\
\text { own identity may } \\
\text { differ from her past } \\
\text { or future students, } \\
\text { offering a clear } \\
\text { example. S/he } \\
\text { expresses respect } \\
\text { for others' } \\
\text { experience. S/he } \\
\text { expresses humility } \\
\text { in the face of what } \\
\text { s/he may not know } \\
\text { about others' } \\
\text { experience. }\end{array}$ & $\begin{array}{l}\text { Candidate } \\
\text { demonstrates an } \\
\text { emerging } \\
\text { understanding that a } \\
\text { teacher has an } \\
\text { ethical } \\
\text { responsibility to } \\
\text { acknowledge the } \\
\text { ways in which } \\
\text { his/her experience } \\
\text { may differ from } \\
\text { students and show } \\
\text { respect for those } \\
\text { differences. S/he } \\
\text { acknowledges that } \\
\text { her own experience } \\
\text { may differ from her } \\
\text { past or future } \\
\text { students but does } \\
\text { not explain how. } \\
\text { S/he may not yet } \\
\text { express respect for } \\
\text { others' experience. } \\
\text { S/he may not yet } \\
\text { express humility in } \\
\text { the face of what s/he } \\
\text { may not know about } \\
\text { others' experience. }\end{array}$ & $\begin{array}{l}\text { Candidate } \\
\text { demonstrates } \\
\text { no } \\
\text { understanding } \\
\text { that a teacher } \\
\text { has an ethical } \\
\text { responsibility } \\
\text { to } \\
\text { acknowledge } \\
\text { the ways in } \\
\text { which his/her } \\
\text { experience } \\
\text { may differ } \\
\text { from students } \\
\text { and show } \\
\text { respect for } \\
\text { those } \\
\text { differences. } \\
\text { Or, the } \\
\text { candidate } \\
\text { demonstrates } \\
\text { disrespect for } \\
\text { difference. }\end{array}$ \\
\hline
\end{tabular}




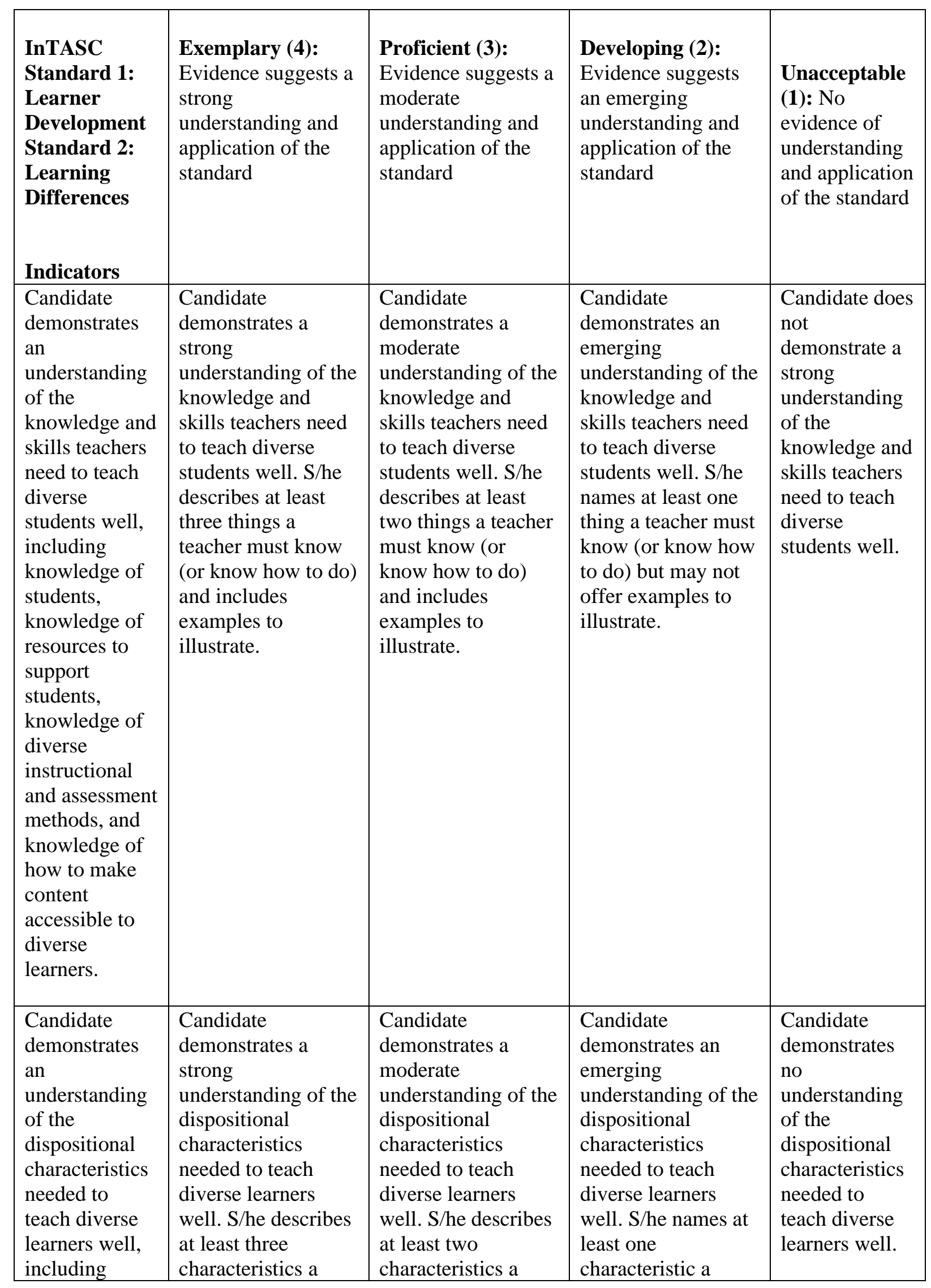




\begin{tabular}{|l|l|l|l|l|}
\hline $\begin{array}{l}\text { openness, } \\
\text { acceptance, } \\
\text { understanding, } \\
\text { and a }\end{array}$ & $\begin{array}{l}\text { teacher must } \\
\text { possess and includes } \\
\text { examples to } \\
\text { commitment to } \\
\text { helping every } \\
\text { child succeed. }\end{array}$ & $\begin{array}{l}\text { teacher must } \\
\text { possess and includes } \\
\text { examples to }\end{array}$ & $\begin{array}{l}\text { teacher must } \\
\text { possess but may not } \\
\text { include examples to } \\
\text { illustrate. }\end{array}$ & \\
& & & & \\
\end{tabular}

\section{APPENDIX B: DIVERSITY IN EDUCATION COURSE OBJECTIVES}

\section{Course Description and Objectives}

This course is designed to clarify and develop future teachers' understanding of diversity and teaching children from diverse backgrounds through an exploration of multicultural education. Specifically, this course is designed to examine 1) historical and curricular perspectives on multicultural education; 2) the nature and function of culture; 3 ) the development of individual and group cultural identity; 5) definitions and implications of diversity, and 6) the influences of culture on learning, development, and pedagogy. In this respect, the course prepares students to critically examine the social, cultural, and political foundations of these approaches in public education. In this course, diversity refers to all ways in which people differ, including ethnicity, language, religious practices, sexual preferences, disability, socioeconomic status, gender, and other differences. It therefore provides opportunities to learn more about cultural pluralism and diversity, confront racism and other biases, view history and current events from a variety of perspectives, and think about teaching in a multicultural manner within any school context.

Students will:

- Examine historical and curricular perspectives on multicultural education.

- Examine the nature and function of culture and how history and culture shape worldviews.

- Examine the development of his/her own cultural identity and learning preferences.

- Develop and apply strategies for observing, analyzing, and comparing differences related to culture, family structures, abilities/disabilities, ethnicity, language, religious practices, sexual preferences, disability, socio-economic status, and gender.

- Articulate strategies for teaching culturally diverse students and creating inclusive classrooms.

- Identify school practices and policies that perpetuate and maintain achievement gaps, including negative stereotypes, related to race, class, persons with disabilities, gender, sexual orientation, and other forms of prejudice and discrimination.

- Identify educators' cultural practices and expectations that perpetuate and maintain achievement gaps.

- Identify strategies that creatively deal with challenges and differences between the culture of educators and students.

- Identify assets and values of diverse populations to enhance student learning

\section{Standards}

This course will address the following standards and indicators related to the Education Department student learning objectives, which are set by state and national accrediting agencies:

InTASC Standard 1: Learner Development - The teacher understands how learners grow and develop, recognizing that patterns of learning and development vary individually within and across the cognitive, linguistic, social, emotional, and physical areas, and designs and implements developmentally appropriate and challenging learning experiences.

InTASC Standard 2: Learning Differences - The teacher uses understanding of individual differences and diverse cultures and communities to ensure inclusive learning environments that enable each learner to meet high standards. 
- Candidate demonstrates understanding of different types of diversity he/she may encounter among students, including developmental, cognitive, linguistic, social, emotional, physical, cultural, socio-emotional, familial and in terms of gender and sexuality.

- Candidate demonstrates understanding that a teacher has a responsibility to provide high quality educational opportunities for all children.

- Candidate demonstrates understanding that a teacher has a responsibility to know his/her students well.

- Candidate demonstrates understanding that a teacher has a responsibility to collaborate with students, families and school community members to meet the needs of diverse learners.

- Candidate demonstrates understanding that a teacher has an ethical responsibility to acknowledge the ways in which his/her experience may differ from students and show respect for those differences.

- Candidate demonstrates an understanding of the knowledge and skills teachers need to teach diverse students well, including knowledge of students, knowledge of resources to support students, knowledge of diverse instructional and assessment methods, and knowledge of how to make content accessible to diverse learners.

- Candidate demonstrates an understanding of the dispositional characteristics needed to teach diverse learners well, including openness, acceptance, understanding, and a commitment to helping every child succeed. 